\title{
KETERAMPILAN MANAJERIAL KEPALA SEKOLAH \\ DALAM MENINGKATKAN KINERJA GURU \\ DI SMK YASMIDA AMBARAWA \\ KABUPATEN PRINGSEWU
}

\author{
Syeh Al Ngarifin, Muhtarom, Ulfah Ummurohmi \\ Jl. Raya Wonokriyo Gadingrejo Pringsewu \\ Email: stitpringsewu@gmail.com
}

\begin{abstract}
This study aims to determine how the headmaster of the SMK Yasmida Ambarawa foster and control the employee for the advancement of teachers and the school, including the pedagogical side and the professionalism of the teacher-led. SMK Yasmida Ambarawa is a private school in sub urban region with the varied of human resource and entry 8 major categories of school-based pilot vocational national level. This is a challenge and a great effort for a headmaster with the reality high enthusiasts to reach thousands students, is a good managerial proof applied by headmaster. This is the one interesting researcher for reviewing more about skills in vocational headmaster of SMK Yasmida Ambarawa.

Headmaster of SMK Yasmida Ambarawa have done menagerial through of process; a) preparation of work plan of the school, either half or annual, preparing curriculum simultaneously divide tasks to all teachers and employees along with the letter of assignment and schedule. b) leads the coordination and meeting, providing quick and direct information, conduct periodic guidance for teachers and employees. C) improve the welfare of teachers with loads attention honorarium based tasks, perform evaluations comprehensive and rewards for teachers its achievement.
\end{abstract}

\begin{abstract}
Abstrak
Penelitian ini bertujuan untuk mengetahui bagaimana kepala sekolah SMK Yasmida Ambarawa membina dan mengontrol guru dan pegawai untuk kemajuan sekolah tersebut, termasuk sisi pedagogis dan profesionalitasnya. SMK Yasmida Ambarawa merupakan sekolah swasta yang berada di wilayah sub urban dengan sumber daya manusia yang bervariasi serta masuk 8 besar kategori sekolah berbasis kejuruan percontohan tingkat nasional. Hal ini merupakan tantangan dan usaha besar bagi seorang kepala sekola dengan realitas peminat sekolah yang cukup tinggi mencapai ribuan siswa adalah bukti bagusnya managerial yang diterapkan oleh kepala sekolah. Hal inilah yang menarik peneliti untuk menngkaji lebih dalam tentang keterampilan SMK Yasmida Ambarawa.

Kepala SMK Yasmida Ambarawa telah melakukan menejerialnya melaului proses; a) penyusunan rencana kerja sekolah, baik semester maupun tahunan, menyusun kurikulum sekaligus membagi tugas kepada seluruh guru dan pegawai beserta surat tugas dan jadwalnya. b) memimpin koordinasi dan pertemuan, pemberian information langsung dan cepat, melakukan pembinaan berkala bagi guru dan pegawai. c) meningkatkan kesejahteraan guru dengan memperhatikan honorarium berdasarkan beban tugas, melakukan evaluasi secara menyeluruh dan memberikan penghargaan bagi guru yang berprestasi.
\end{abstract}

Kata kunci: Keterampilan Kepala Sekolah, Kinerja Guru 


\section{A. PENDAHULUAN}

Pendidikan memegang peranan yang sangat penting dalam menjamin kelangsungan kehidupan berbangsa dan bernegara, karena pendidikan merupakan sarana untuk meningkatkan kualitas sumber daya manusia (Dewi, IKAS., dkk. 2014:2). Pendidikan juga merupakan salah satu cara untuk mencapai tujuan pembangunan bangsa. Dalam pembukaan UUD 1945 disebutkan bahwa tujuan pendidikan adalah untuk mencerdaskan kehidupan bangsa.

Keinginan pemerintah untuk melaksanakan reformasi dalam kehidupan berbangsa dan bernegara dibidang pendidikan terlihat dengan dikeluarkannya Undang-Undang Nomor 20 tahun 2003 tentang Sistem Pendidikan Nasional. Adapun substansi dari Undang-Undang Sisdiknas tersebut nampak dari visinya: yaitu, Terwujudnya sistem pendidikan sebagai pranata sosial yang kuat dan berwibawa untuk memberdayakan semua warga negara Indonesia, berkembang menjadi manusia yang berkualitas, sehingga mampu proaktif menjawab tantangan zaman (Arifin, 2003:51).

Di antara upaya untuk meningkatkan mutu pendidikan adalah dengan cara meningkatkan keterampilan manajemen pimpinan institusi lembaga pendidikan (Hidayati. 2014:43) . Karena dengan keterampilan manajemen yang baik, maka sebuah institusi pendidikan akan dapat berkembang secara optimal sebagaimana yang diharapkan.

Begitu pentingnya peranan manajemen dalam kehidupan apalagi di dunia pendidikan sehingga mengharuskan kita untuk mempelajari, menghayati, dan menerapkanya untuk mencapai tujuan yang sudah di cita-citakan. Mismanagement (salah urus) harus dapat dihindarkan, karena hal tersebut akan menimbulkan kerugian bahkan tujuan yang diharapkan tidak akan dapat tercapai. Terkait ini, Allah berfirman dalam QS: As-Sajdah: 5:

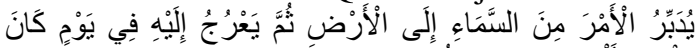

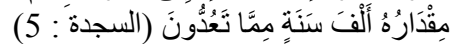
Artinya: Dia mengatur urusan dari langit ke bumi, kemudian (urusan) itu naik kepadanya dalam satu hari yang kadarnya adalah seribu tahun menurut perhitunganmu (QS: Al Sajdah : 05)

Setiap kepala sekolah dituntut untuk memiliki keterampilan manajerial. Keterampilan manajerial adalah kemampuan seseorang dalam mengelola sumber daya organisasi berdasarkan kompetensi yang di tetapkan dalam rangka mencapai tujuan yang telah ditetapkan dalam rangka mencapai tujuan yang telah ditentukan. Keterampilan manajerial ini diperlukan untuk melaksanakan tugas sebagai manajer dalam pendidikan secara efektif (Siagian, 2002:12).
Menurut Robert L. Katz (dikutip oleh Sudarman dalam Motivasi Kepemimpinan dan efektifitas kelompok) Kepala Sekolah sebagai pemimpin pendidikan sebagai administator, sebagai manajer pendidikan harus memiliki kompetensi yang di dalamnya temasuk keterampilan dalam melaksanakan tugasnya keterampilan yang harus dimiliki tersebut adalah keterampilan teknis (Tehnical skill). Keterampilan teknis merupakan keterampilan teoritis kedalam tindakan-tindakan praktis, keterampilan dalam menggunakan metode, teknis, prosedur atau prakarsa melalui $S k i l l)$, Keterampilan hubungan manusia (Human Relation Skill) dan keterampilan konsetual skill (conceptual skill) keterampilan taktik yang baik dan menyelesaikan tugas nya secara sistimatis, Danim, (111:2011). Pendapat yang sama dikemukakan oleh Steers, Ungson, dan Mowday, '"managers at different levels require or use these three managerial skill (conceptual, human, technical) in diff erents proporsition' (manajer pada semua tingkatan memerlukan tiga keterampilan (konseptual, kemanusiaan dan teknikal) yang berbeda proporsinya, Higgins (34:1985).

Adanya ketiga kemampuan tersebut seharusnya kepala sekolah mampu meningkatkan kinerja guru yang ada dilingkungan sekolah. Hadari Nawawi (1996:34) mengartikan kinerja sebagai prestasi seseorang dalam suatu bidang atau keahlian tertentu, dalam melaksanakan tugasnya atau pekerjaannya yang didelegasikan dari atasan dengan efektif dan efisien. Dari pendapat di atas dapat disimpulkan bahwa kinerja merupakan suatu wujud perilaku seseorang atau organisasi dengan orientasi prestasi. Kinerja seseorang dipengaruhi oleh beberapa faktor seperti: Ability, capacity, held, incentive, environment dan validity. Adapun ukuran kinerja menurut T.R. Mitchell (Direktorat Tenaga Kependidikan, 2008:23), dapat dilihat dari empat hal, yaitu:

a. Quality of work - Kualitas hasil kerja

b. Promptness - Ketepatan waktu menyelesaikan pekerjaan

c. Initiative - Prakarsa dalam menyelesaikan pekerjaan

d. Capability - Kemampuan menyelesaikan pekerjaan

e. Comunication - Kemampuan membina kerjasama dengan pihak lain.

Dari hasil pra survey tentang keterampilan manjerial kepala sekolah bahwa keterampilan manajerial kepala SMK Yasmida Ambarawa dapat penulis sajikan pada hasil wawancara dengan kepala sekolah dan beberapa guru bahwa : "Keterampilan yang dimiliki oleh Kepala SMK Yasmida Ambarawa sangat luas mulai dari 
menyusun laporan keuangan, program pembelajaran, membuat kebijakan sekolah, penataan ruang sekolah, dan lain-lain." Dalam tugasnya kepala sekolah sudah memiliki keterampilan teknis yang baik walaupun masih ada hal-hal yang belum bisa dilaksanakan karena belum adanya fasilitas sekolah yang memadai. Tetapi semua masih bisa diatasi sehingga tidak akan menghambat pelaksanaan tugas kepala sekolah.

Kepala SMK Yasmida Ambarawa mampu membuat kebijakan-kebijakan yang membuat semua kegiatan sekolah dapat terlaksana dengan baik sehingga proses pembelajaran dapat berjalan dengan baik. Hal ini dapat dibuktikan dengan berbagai prestasi yang tealh diperoleh oleh SMK Yasmida dari level lokal maupun nasional. Pada tahun 2015 SMK Yasmida masuk dalam 8 besar Kategori Sekolah Menengah Kejuruan Percontohan tingkat Nasional. Selain itu kepala SMK Yasmida Ambarawa juga merupakan orang yang memiliki kemapuan berkomunikasi yang baik dalam menyelenggarakan proses pembelajaran. Hal inilah yang kemudian menurut penulis sangat menarik untuk dilakukan sebuah penelitian tentang keterampilan managerial kepala sekolah SMK Yasmida Ambarawa.

\section{B. TUJUAN}

Tujuan dari penelitian ini adalah: Untuk mengetahui keterampilan manajerial kepala sekolah dalam meningkatkan kinerja guru di SMK Yasmida Ambarawa kabupaten Pringsewu. Selain itu juga untuk mengetahui bagaimana kepala SMK Yasmida Ambarawa membina dan mengontrol guru dan pegawai untuk kemajuan sekolah tersebut, termasuk sisi pedagogis dan profesionalitas para guru yang dipimpin.

\section{METODOLOGI PENELITIAN}

Jika dikaitkan dengan tujuan penelitian ini yaitu untuk mengetahui bagaimana kepala SMK Yasmida Ambarawa membina dan mengontrol guru dan pegawai untuk kemajuan sekolah tersebut, termasuk sisi pedagogis dan profesionalitas para guru yang dipimpin serta teknik pengumpulan datanya, maka penelitian yang penulis lakukan termasuk dalam jenis penelitian lapangan (field research) karena penelitian ini memiliki tujuan mendeskripsikan dan menganalisa fenomena, peristiwa, sikap, kepercayaan, individu maupun kelompok ( Sukmadinata, 2005:96).

Penelitian ini menggunakan pendekatan kualitatif, karena penelitian ini bertujuan untuk mendeskripsikan obyek yang akan diteliti dengan melakukan observasi (observation), wawancara secara mendalam (indepth interviewing), dan metode lain yang mampu menghasilkan data deskriptif mengenai obyek.

\section{PEMBAHASAN}

\section{Keterampilan Manajerial Kepala Sekolah}

Keterampilan managerial kepala sekolah SMK Yasmida secara umum sudah mampu diterapkan dengan baik dari mulai keterampilan konseptual, keterampilan hubungan dengan manusia dan keterampilan tekhnikal. Hal ini dapat dibuktikan dengan perkembangan SMK Yasmida Ambarawa mulai dari pendiriannya sampai pada saat sekarang ini. Pada periode 2004-2007 SMK Yasmida bernama SMK Negeri Gading Rejo kelas jauh di Pondok Pesantren Yasmida Ambarawa. Kemudian pada tahun berikutnya SMK Yasmida sudah menjadi lembaga pendidikan yang berada di bawah naungan Yayasan Miftahul Huda sendiri.

Pada Tahun 2004 - 2007 SMK Yasmida baru membuka jurusan Tehnik Kendaraan Ringan (TKR) dengan jumlah siswa 32 siswa. Setelah mandiri SMK Yasmida mulai menyelenggarakan pendidikan formalnya, dan membuka kejuruan baru yaitu, Tehnik Komputer Jaringan (TKJ) pada Tahun 2008. Kemudian pada Tahun 2010 SMK Yasmida Ambarawa Membuka kembali Kejuruan baru yaitu Tehnik Sepeda Motor (TSM). Pada Tahun 2012 SMK Yasmida membuka Kejuruan Keperawatan/Kesehatan (KK), Pada Tahun 2015 SMK YASMIDA Ambarawa Membuka Kejuruan Multi Media (MM), sehingga di pembelajaran pada tahun 2012 2016 kejuruan yang ada di SMK YASMIDA ada lima (5) kejuruan, di antaranya Tehnik Kendaraan Ringan (TKR), Tehnik Komputer dan Jaringan (TKJ), Tehnik Sepeda Motor (TSM), Keperawata/Kesehatan (KK), dan Multi Media (MM). Jumlah siswa keseluruhan dari ke 5 jurusan tersebut pada Tahun 2015 2016 mencapai 1313 siswa.

\section{a. Keterampilan Konseptual}

\section{1) Pengambilan Keputusan}

Dalam hal pengambilan keputusan, kepala sekolah mampu mengambil keputusan dengan tepat. Menurut Aminudin, S.Pd. I, kepala sekolah dalam mengambil keputusan sangat tepat dan sesuai dengan kondisi dan masalah yang sedang dihadapi. Dalam setiap masalah yang dianggap penting, kepala sekolah biasanya mengundang guru untuk rapat membahas masalah yang dihadapi tersebut. Bila menjelang ujian nasional (UN), beberapa bulan sebelumnya kepala sekolah menggelar rapat untuk mengevaluasi persiapan dan kondisi peserta didik, apakah peserta didik telah siap menghadapi ujian, 
apakah materi telah disampaikan dan terserap seluruhnya oleh peserta didik, dan apabila dianggap belum memenuhi target, maka kepala sekolah akan memerintahkan kepada guru untuk melakukan jam tambahan. Karena Sudah menjadi Misi SMK Yasmida Ambarawa mencetak siswa berprestasi dan berdaya saing didunia kerja, maka program sekolah tidak hanya sukses dibidang UN saja akan tetapi lulusannya memiliki keterampilan dan kemandirian dalam dunia kerja. Misi itu tidak akan tercapai tanpa dukungan dan partisipasi dari para guru (khususnya). Khusus dalam menghadapi UN siswa kelas XII mendapatkan penambahan jam pelajaran pada semester 5 dan pada semester 6 tiga hari untuk pelajaran praktek (produktif) digunakan penambahan materi UN" (Mustofa, Wawancara, 15 Desember 2015).

Hal ini dikuatkan dengan pernyataan yang disampaikan oleh kepala TU SML Yasmida bahwa "Dalam membuat keputusan, kepala sekolah cenderung bersifat bottom up dengan mekanisme; pertama, mengidentitikasi berbagai komponen yang menjadi bahan pertimbangan dalam membuat keputusan dari seluruh komunitas sekolah; kedua, pengumpulan dan pemilihan komponenkomponen sesuai dengan Skala prioritas; ketiga, mempersiapkan draft pembuatan keputusan untuk dibahas pada proses penetapan Keputusan yang akan menjadi salah satu pijakan pelaksanaan organisasi dan sebagai dasar dalam pembuatan kebijakan.

2) Penyusunan Program

Berdasarkan program tahunan kepala sekolah, kegiatan penyusunan program pengajaran dilaksanakan setiap bulan Juli tahun berjalan dan evaluasi hasil belajar dilaksanakan pada bulan Desember dan Juni, (Prota SMK Yasmida, Tahun Pelajaran 2015-2016).

Dalam kegiatan penyusunan program, semua dewan guru dilibatkan dalam rapat penyusunan program pengajaran yang dilaksanakan pada akhir tahun ajaran. Dalam rapat yang dipimpin oleh bapak kepala sekolah tersebut dilakukan pembagian tugas mengajar, kurikulum yang akan digunakan dan sarana dan prasarana yang dibutuhkan dalam kegiatan pembelajaran pada tahun ajaran berjalan.

Dalam rapat tersebut semua dewan guru diberi kebebasan dalam memberikan usul, saran dan pendapat demi tercapainya tujuan bersama. Yang perlu dipahami disini adalah walaupun dalam rapat terbuka terdapat kebebaskan dalam menyampaikan pendapat tetapi ada etika yang tetap dipegang oleh peserta rapat yakni bebas yang tidak kebablasan atau kelewatan. Demikian pula sebaliknya yang dilakukan oleh Kepala Sekolah demi untuk memajukan sekolah yang dipimpinnya dalam membuat dan menentukan kebijakan tidak sewenang-wenang dengan cara memaksakan kehendak.

\section{b. Keterampilan Berkomunikasi}

1) Membangun pola komunikasi

Dalam membangun komunikasi kepala sekolah tidak hanya fokus pada pengelola sekolah, staf maupun siswa di sekolah akan tetapi lebih jauh kepada masyarakat lingkungan sekolah. Sebagaimana hasil wawancara kepala sekolah, sebagai berikut:

"Sebagai kepala sekolah saya melakukan komunikasi dua arah dengan baik dengan warga sekolah atau pun dengan masyarakat. Saya menjelaskan kepada semua stakeholder semua program yang telah saya buat program kerjanya diawal tahun, agar dipahami oleh semua pihak".

Dalam memberikan bimbingan, kepala sekolah lebih mengedepankan rasa dan bersifat kekeluargaan. Rasa kekeluargaan senantiasa beliau bangun dengan baik, salah satu bentuknya adalah setiap kegiatan dikerjakan secara bersama dan menyeluruh, dengan asumsi bahwa setiap kepanitiaan merupakan sebuah team work dan diberikan kesempatan secara bergiliran. Dalam hal lain Bapak Ihsanuddin tidak pernah membedakan para bawahan, siapa yang salah akan ditegur dan diingatkan serta diberikan jalan keluarnya. Kepala sekolah senantiasa menjadikan bawahan sebagai mitra bahkan dalam rapat tidak pernah menyebut bapak/ibu guru mesti dengan istilah teman-teman, tidak hanya itu diantara guru sering diajak musyawarah dan kerjasama serta diberikan tawaran, seperti siapa yang perlu menghadiri sebuah seminar, pelatihan, menjadi Panitia, bahkan sebelum dihasilkan suatu keputusan, baik guru maupun karyawan senantiasa diajak musyawarah dan diminta pendapatnya demi untuk kemajuan sekolah, (Sukindar,Wawancara, tanggal 10 Desember 2015).

Kepala SMK Yasmida Ambarawa cukup komunikatif dalam menyampaikan segala hal yang dengan kepemimpinannya. Dia mampu memainkan peranannya sebagai seorang manajer atau pimpinan yang baik komunikasinya yang di dua arah antara orang lain dan dirinya. Sering meminta informasi dan masukan tentang hubungan kerja antara dirinya dengan orang lain, (Observasi , tanggal 2 Desember 2015).

2) Melakukan pengawasan

Kepala sekolah memiliki tugas untuk 
melakukan pengawasan dan pembinaan kepada guru dan tenaga kependidikan serta administrator. Kepala sekolah berusaha untuk melakukan pengawasan terhadap semua yang ada disekolah termaksud terhadap guru dan siswa. Akan tetapi ada guru yang kurang suka saat ditegur jika mereka melakukan kesalahan, sehingga ia menemui kesulitan untuk memberi pembinaan kepada mereka, Observasi , tanggal 2 Desember 2015).

Pengawasan yang dilakukan kepala sekolah berlaku untuk guru maupun siswa berdasarkan peraturan yang berlaku disekolah. Namun hasil dari pengawasan yang dilakukan tidak dibahas lebih lanjut lagi, sehingga guru yang kurang baik kinerjanya tidak kurang menyadari kesalahannya tersebut. Akan tetapi jika kepala sekolah melakukan pembinaan terhadap guru yang kurang tertib bisa meningkatkan kinerja guru tersebut

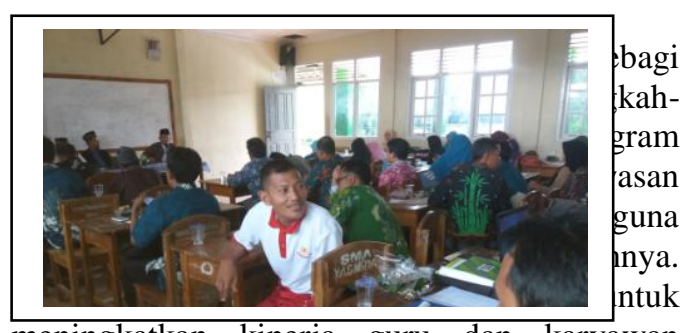

meningkatkan kinerja guru dan karyawan maupun untuk pengembangan sekolah. Hasil supervisi dikomunikasikan agar menjadi timbal balik bagi kepentingan lembaga maupun kepentingan peningkatan kualitas guru atau karyawan.

Kepala sekolah melakukan pengawasan terhadap siswa dalam semua kegiatan mereka baik intrakurikuler maupun ekstrakurikuler, termaksud juga dalam hal kedisiplinan. Jika ada hal yang kurang baik dalam pengawasan saya akan saya sampaikan supaya ada perbaikan. Kepala sekolah selalu melakukan pengawasan terhadap semua kegiatan disekolah, termaksud pengawasan terhadap guru dan siswa. Jika guru mempunyai kinerja baik akan diberikan reward dan jika kinerja guru kurang maka kepala sekolah akan memberikan pembinaan sehingga guru bisa membuat perubahan. Kepada siswapun kepala sekolah akan memberikan sanksi tegas kepada siswa yang tidak tertib. Dalam kaitannya dengan supervisi pendidikan, saya melakukan langkahlangkah antara lain: Melaksanakan program supervisi melalui adanya program supervisi kelas, dadakan (inspeksi) dan kegiatan ekstrakurikuler. Supervisi dilakukan dengan membuat instrumen guna mengukur tingkat keberhasilannya. memanfaatkan hasil supervisi untuk meningkatkan kinerja guru dan karyawan maupun untuk pengembangan Sekolah, (Hasil Wawancara Kepala Sekolah, Tanggal 15
Desember 2015).

\section{3) Memberikan Motivasi}

Kepala sekolah selalu berusaha untuk memberi motivasi kepada guru dan karyawan terutama yang masih muda dan belum disibukkan oleh urusan lain untuk senantiasa meningkatkan sumber daya baik itu melanjutkan studinya maupun mengikuti berbagai pelatihanpelatihan. Karena perkembangan zaman yang semakin maju tentu tuntutan peningkatan sumber daya sangat diperlukan, kepala sekolah tidak pernah menentukan, siapa saja yang mau meningkatkan kualitas dirinya akan diberi kesempatan seluas-luasnya, studi lanjut misalnya setiap ada informasi dari Dinas Pendidikan maupun Provinsi selalu ditawarkan secara luas kepada para guru untuk mengikuti seleksi, atau kadang guru berusaha mencari sendiri kuliah S-2 atau pendidikan dan latihan lainnya, kepala sekolah hanya memberikan rekomendasi, (Hasil Wawancara Kepala Sekolah, Tanggal 15 Desember 2015).

Dalam mengapresiasi kinerja guru,kepala sekolah tidak enggan memberikan penghargaan terhadap hasil kerja yang maksimal tetapi juga tidak segan dalam hal mengkoreksi terhadap guru atau karyawan yang lainnya, bila melihat hal yang kurang sesuai. Kepala sekolah terus mendorong prestasi para guru dan staf sesuai kemampuan masing-masing. Kepala sekolah juga berusaha menciptakan suasana kerja yang penuh kekeluargaan, yaitu adanya saling percaya, saling menghormati dan saling menghargai, (Hasil Wawancara Guru, Tanggal 10 Desember 2015).

Menurut pengamatan penulis, Kepala sekolah selalu memotivasi denga nmemberikan penghargaan dan sanksi yang sesuai dengan aturan-aturan yang berlaku. Kepala sekolah selalu membangun suasana kinerja yang kondusif misalnya menjaga persatuan dan kebersamaan antar warga sekolah. Kepala sekolah juga berusaha untuk mendorong kinerja guru agar lebih baik lagi, (Observasi, tanggal 2 Desember 2015).

\section{c. Keterampilan Teknis}

\section{Pemberian Wewenang}

Salah satu kompetensi profesional kepala sekolah adalah merupakan kepemimpinan dalam pekerjaan, dengan subdimensi mengembangkan profesional kebijaksanaan sekolah, dan mendistribusikan kewenangan kepada bawahannya sesuai dengan job description. Dalam hal ini sebagaimana disampaikan informan pertama, yakni kepala sekolah, sebagai berikut:

"Dalam menjalankan manajemen sekolah saya menjalankan tugas saya sesuai dengan aturan yan berlaku, dan memberikan kewenangan 
tugas kepada wakil kepala sekolah maupun staf yang lain, sesuai dengan tugas dan tanggung jawab mereka masing-masing. Akan tetapi jika tugas itu bisa saya jalankan sendiri, maka saya lebih memilih untuk melakukannya sendiri tanpa merepotkan bawahan saya. Kepala sekolah menggunakan kewenangan sesuai dengan ketentuan yang telah disepakati dan tunduk terhadap aturan yang telah ditetapkan oleh pemerintah. Kepala sekolah juga menyusun struktur organisasi dan sesuai kewenangan yang di miliki kepala sekolah memilih orang yang kompeten untuk menjalankan tugas, kemudian saya membuat job description dan semua pekerjaan dibagi habis sesuai dengan fungsinya masing-masing", (Mustofa, Wawancara Tanggal 15 Desember 2015).

Kepala sekolah mempunyai kewenangan yang luas dalam menjalankan tugasnya, kadangkadang beliau melimpahkan tugasnya kepada bawahan tetapi itu terjadi jika beliau sedang ada tugas luar. Jika sedang berada di sekolah, hampir semua tugas kepala sekolah dijalankan sendiri oleh beliau. Kewenangan yang dimiliki oleh kepala sekolah SMK Yasmida Ambarawa sangat luas dan otonom karena menjadi figur sentral dalam memegang kewenangan yang ada di sekolah sesuai dengan jabatan, akan tetapi kepala sekolah tidak demikian, beliau lebih menghormati dan menghargai seluruh potensi yang ada dengan melimpahkan sebagian wewenang sesuai dengan tingkatanya, (Observasi, tanggal 2 Desember 2015).

Dalam menyelenggarakan proses belajar mengajar kepala sekolah dan untuk memajukan kualitas pendidikan di SMK Yasmida Ambarawa, kepala sekolah selalu mengikutsertakan komite dalam setiap pengambilan keputusan. Kepala sekolah diberikan kewenangan sepenuhnya dari komite untuk menyelenggarakan pelaksanaan proses belajar mengajar sesuai dengan aturan. Dalam hal ini komite dilibatkan dalam berbagai keputusan penting yang menyangkut kemajuan kualitas pendidikan di SMK, (Observasi, tanggal 2 Desember 2015).

Dalam bidang pendidikan, keterampilan teknik adalah kemampuan kepala sekolah dalam menanggapi dan memahami serta cakap menggunakan metode-metode termasuk pengajaran, yaitu pengetahuan keuangan, pelaporan, penjadwalan, dan pemeliharaan.

2. Memberikan Arahan

Untuk mengefektifkan kinerja dari para bawahannya dan demi tercapainya tujuan pendidikan, maka kepala sekolah senantiasa memberikan arahan kepada bawahannya. kemajuan sebuah lembaga pendidikan tentu harus mendapat dukungan dari berbagai pihak dan berbagai aspek, namun guru sebagai ujung tombak dalam meningkatkan kualitas siswa dan karyawan sebagai petugas administrasi dalam kegiatan belajar mengajar perlu untuk ditingkatkan kemampuan profesionalnya. Untuk mencapai semua itu perlu diperhatikan bahwa semua yang terlibat dalam proses belajar mengajar utamanya para guru perlu dikembangkan dan ditingkatkan. Maka dari itu kepala sekolah senantiasa berupaya agar guru lebih meningkatkan lagi kinerjanya, dengan cara mengikut sertakan ke berbagai kegiatan sekolah baik di bidang kesiswaan, Prakerin, Kebersihan dan keindahan lingkungan, dll. Jadi guru bukan hanya sekedar mengajar namun terlibat dalam berbagai kegiatan sekolah. Demikian pula kepala sekola selalu memberikan apresiasi terhadap guru yang memiliki prestasi atau meraih kesuksesan dalam menjalankan tugasnya baik dalam hal akademik maupun non akademik, (Hasil Wawancara Guru, Tanggal 10 Desember 2015).

\section{Proses Penetapan Kebijakan}

Dalam mengambil kebijakan kepala sekolah melaksanakan rapat khusus untuk menampung usulan dan aspirasi. Dari masukan-masukan yang ada kepela sekolah mengambil yang terbaik untuk ditetapkan sebagai suatu kebijakan dengan memperhatikan semua situasi dan kondisi yang ada disekolah. Dalam menetapkan suatu kebijakan, kepala sekolah biasanya mengadakan musyawarah bersama dewan guru juga melibatkan komite sekolah untuk memberikan aspirasi. Setelah mempertimbangkan semua aspirasi yang ada barulah ditetapkan kebijakan yang dinilai bermanfaat bagi semua warga sekolah. Untuk menghasilkan kebijakan yang maksimal dalam kerangka, MBS, kepala sekolah pastikan dulu untuk mendapatkan informasi yang cukup.

Dalam mengimplementasikan MBS, ada 4 langkah yang saya lakukan antara lain: 1) Sekolah membentuk dewan sekolah yang terdiri dari kepala sekolah, perwakilan guru, orang tua siswa, anggota masyarakat, staf sekolah dan siswa, 2) selanjutnya dewan sekolah melakukan pengukuran kebutuhan sekolah, 3) dewan sekolah mengembangkan perencanaan tindakan yang mencakup tujuan dan sasaran, dan 4) mengambil keputusan untuk membuat program-programt) untuk kemajuan sekolah.

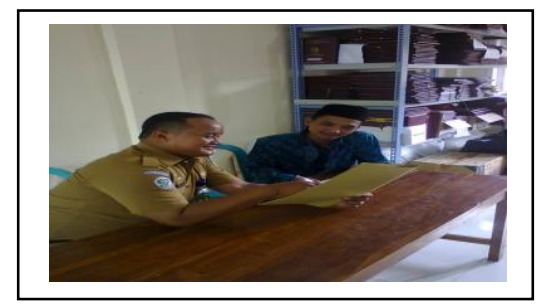


Sebelum diambil kebijakan terlebih dahulu disosialisasikan kepada warga sekolah untuk menampung aspirasi setelah mempertimbangkan usul dan aspirasi maka dibuatlah kebijakan sambil memantau perkembanganya, (Hasil Wawancara TU SMK Yasmida. Tanggal 10 Desember 2015).

Sebelum mengambil kebijakan, biasanya kepala sekolah mengadakan rapat khusus, untuk menampung usulan dan aspirasi, kemudian dimusyawarahkan lerlebih dahulu dengan mendengarkan masukan-masukan dari peserta rapat, yang kemudian diambil keputusan. Setelah itu hasilnya disosialisasikan kepada semua warga sekolah, (Observasi, tanggal 2 Desember 2015).

Ukuran kebijakan yang dibuat oleh lembaga SMK Yasmida dalam rangka kepentingan bersama, sehingga kepala sekolah dalam hal tertentu mengkonsultasikannya kepada komite, dan alhamdulillah selalu mendapat dukungan. setiap pengambilan kebijakan kami selalu memberi tahukan hasilnya kepada komite sekolah sambil memberi hasil manfaat dan madaratnya. Seluruh potensi pengambilan kebijakan diikut sertakan dalam musyawarah untuk diminta usulan dan aspirasi dari seluruh peserta rapat. Hasil pertimbangan yang matang, dijadikan suatu kebijakan. Melihat setiap keputusan yang sudah disepakati bersama sebagai bahan musyawarah.

\section{Kinerja Guru}

a. Kemampuan Pembelajaran

Perencanaan kegiatan pembelajaran merupakan penjabaran operasional dari kurikulum, sedangkan aplikasi dari perencanaan akan terlihat dalam kegiatan pembelajaran. Perencanaan pembelajaran memiliki peranan yang sangat penting dalam proses pembelajaran, terutama sebagai alat proyeksi kegiatan -kegiatan yang akan dilakukan selama pembelajaran. Fungsi perencanaan pembelajaran sebagai pedoman atau panduan kegiatan menggambarkan hasil yang akan dicapai, sebagai alat kontrol dan evaluasi. Bentuk perencanaan pembelajaran adalah silabus pembelajaran dan rencana pelaksanaan pembelajaran (Hasil Wawancara Guru, Tanggal 10 Desember 2015).

Berdasarkan program tahunan kepala sekolah, kegiatan penyusunan program pengajaran dilaksanakan setiap bulan juli tahun berjalan dan evaluasi hasil belajar dilaksanakan pada bulan Desember dan Juni, (Prota SMK Yasmida
Ambarawa, Tahun Pelajaran 2015/ 2016).

Dalam kegiatan penyusunan program, semua dewan guru dilibatkan dalam rapat penyusunan program pengajaran yang dilaksanakan pada akhir tahun ajaran. Dalam rapat yang dipimpin oleh bapak kepala sekolah tersebut dibagikan pembagian tugas mengajar, kurikulum yang akan digunakan serta sarana dan prasarana yang dibutuhkan dalam kegiatan pembelajaran pada tahun ajaran berjalan.

Dari data yang berhasil dihimpun oleh penulis selama melakukan penelitian didapatkan data bahwa guru telah mampu membuat dan melengkapi perencanaan pembelajaran melalui pembuatan Perencanaan Program Tahunan (PROTA), Perencanaan Program semester (PROMES), membuat Silabus, dan membuat Rencana Program Pembelajaran (RPP) dengan baik. Namun dari sejumlah guru yang ada di SMK Yasmida Ambarawa, diketahui bahwa masih ada guru yang tidak membuat RPP ketika akan melaksanaakan kegiatan pembelajaran dengan alasan yang klasik yaitu malas, kecuali bila akan ada pemeriksaan (Observasi, tanggal 2 Desember 2015).

Kepala sekolah tidak pernah membedabedakan, semua guru wajib membuat RPP sebelum memulai pembelajaran. RPP itu biasanya diperiksa terlebih dahulu oleh kepala sekolah. Terkadang ada yang belum siap, dan ada yang harus menunda mengumpulkan RPP, mereka merasa sedikit kebingungan dalam membuat RPP. Padahal dengan membuat RPP, guru akan tahu kemana tujuan pembelajaran akan diarahkan. Pembuatan perangkat pembelajaran sangat bermanfaat bagi guru, selain penyampaian materi menjadi terarah juga dapat meningkatkan kompetensi guru (Hasil Wawancara Guru, Tanggal 10 Desember 2015).

Dari hasil pemaparan di atas dapat penulis simpulkan bahwa rata-rata guru SMK Yasmida Ambarawa sudah membuat perangkat pembelajaran dengan baik, namun ada sebagian guru yang malas-malasan dalam membuat RPP, sehingga mereka mengumpulkannya juga masih sering terlambat. Hal ini disebabkan oleh kurangnya kemampuan guru dalam menyusun RPP.

b. Kemampuan Melaksanakan Pembelajaran Pembelajaran pada hakikatnya adalah proses sebab-akibat. Guru sebagai pengajar merupakan penyebab utama terjadinya proses pembelajaran siswa, meskipun tidak semua perbuatan belajar siswa merupakan akibat guru yang mengajar. Oleh sebab itu, guru sebagai figur sentral, harus mampu menetapkan strategi pembelajaran yang tepat 
sehingga dapat mendorong terjadinya perbuatan siswa yang aktif, kreatif, produktif, dan efisien

Kegiatan pembelajaran di kelas adalah inti penyelenggaraan pendidikan yang ditandai oleh adanya kegiatan pengelolaan kelas, penggunaan media dan sumber belajar serta penggunaan metode maupun strategi pembelajaran. Semua tugas tersebut merupakan tugas dan tanggung jawab guru yang secara optimal dalam pelaksanaannya menuntut kemampuan guru. Kemampuan menguasai bahan pelajaran sebagai bahan integral dari proses belajar mengajar, jangan dianggap hanya sebagai pelengkap bagi profesi guru. Guru yang bertaraf profesional mutlak harus menguasai bahan yang akan diajarkannya. Penguasaan bahan pelajaran ternyata memberikan pengaruh terhadap hasil belajar siswa.

Kegiatan belajar mengajar yang mencakup kesesuaian metode dengan bahan belajar yang disampaikan, penyajian bahan belajar sesuai dengan tujuan/indikator yang telah ditetapkan, keterampilan dalam menanggapi dan merespon pertanyaan siswa, serta ketepatan dalam penggunaan alokasi waktu yang disediakan

Selanjutnya penulis akan mengemukakan tentang kemampuan guru dalam melaksanakan atau mengelola proses belajar mengajar yang ditandai dengan adanya kegiatan pengelolaan kelas, penggunaan media dan sumber belajar, dan penggunaan metode serta strategi pembelajaran. Adapun yang menjadi indikatornya adalah: mampu membangkitkan motivasi siswa, mampu menggunakan metode mengajar yang bervariasi, mampu menggunakan alat bantu pengajaran, mampu mengatur dan mengubah suasana kelas, mampu memberikan teguran terhadap siswa, mampu memberikan reward dan sangsi pada siswa dan mampu memberikan pujian kepada siswa (Observasi, tanggal 2 Desember 2015).

Dari hasil wawancara ditemukan guru dalam melaksanakan kegiatan pembelajaran sudah membuat perncanaan berupa RPP hanya saja terkadang masih tidak sesuai dengan yang tertuang di dalam RPP (Hasil Wawancara Guru, Tanggal 10 Desember 2015).

\section{c.Kemampuan Melaksanan Evaluasi}

Penilaian (assessment) adalah penerapan berbagai cara dan penggunaan beragam alat penilaian untuk memperoleh informasi tentang sejauh mana hasil belajar peserta didik atau ketercapaian kompetensi (rangkaian kemampuan) peserta didik. Penilaian menjawab pertanyaan tentang sebaik apa hasil atau prestasi belajar seorang peserta didik. Hasil penilaian dapat berupa nilai kualitatif (pernyataan naratif dalam kata-kata) dan nilai kuantitatif (berupa angka). Tujuan evaluasi (penilaian) adalah untuk melihat dan mengetahui proses yang terjadi dalam proses pembelajaran.

Pelaksanaan evaluasi/penilaian hasil pembelajaran terdiri dari ulangan harian, ujian tengah semester (Mid Semester), ujian Semester, dan khusus untuk kelas XII ditambahkan dengan kegiatan Try out, Latihan Ujian Sekolah (LUS), Ujian Sekolah (US), Ujian Praktik dan Ujian Nasional (UN), Ulangan harian dilakukan secara periodik dan ditentukan dalam jangka waktu triwulan, yaitu setiap triwulan setiap guru mata pelajaran diberikan kebebasan melaksanakan penilaian hasil belajar antara 2 sampai dengan 4 kali ulangan harian, jadi dalam satu semester setiap guru mata pelajaran dapat melaksanakan evaluasi pembelajaran antara 4 sampai 8 kali.

Keterampilan teknis kepala sekolah diwujudkan dengan kemampuanya menyusun laporan. Selain itu kepala sekolah juga memberi contoh dalam mendidik misalkan dengan mengajar 6 jam seminggu, sebelum mengajar kepala sekolah membuat program tahunan, program semester, silabus, rencana pembelajaran, analisis dan sistem evaluasi.

Hal ini dilakukan untuk memberi tauladan kepada rekan kerja dan guru-guru yang lain. Dalam kemampuanya dibidang teknis (tehnical skill), kepala sekolah sekolah selalu menyusun data statistik sekolah dan secara tertulis mengarsipkanya sebagai data sekolah. Selain itu, staf tata usaha sangat membantu dalam pembuatan surat-menyurat yang berhubungan dengan sekolah. Salah seorang guru mengemukakan pendapatnya tentang prototype kepala sekolahnya antara lain: meskipun sudah lazim seorang pemimpin memiliki kewenangan yang luas atau otonom, namun beliau lebih menghargai potensi yang dimiliki stafnya, sehingga tidak sedikit terjadi pelimpahan wewenang.

Proses pembuatan keputusan dan kebijakan melalui tahapan-tahapan yang kesemuanya ditempuh dengan musyawarah/rapat komite atau dewan guru. Kepala sekolah dalam pandangan guru SMK Yasmida Ambarawa sebagai seorang yang bijaksana dalam mengambil keputusan. Biasanya kepala sekolah mendengarkan masukan-masukan sebagai data untuk dianalisis. Dalam membuat keputusan pada tingkat sekolah kepala sekolah berkontribusi dengan komite sekolah yang terdiri dari kepala sekolah, pengawas, perwakilan guru, orang tua siswa, anggota masyarakat dan staf sekolah. Untuk mengambil keputusan yang rasional dibutuh kreatifitas. Kreatifitas memungkinkan kepala 
sekolah lebih menghargai dan memahami masalah, termasuk melihat masalah yang tidak dapat dilihat orang lain.

Keterampilan komunikasi (human relations skills) kepala sekolah juga mendapat respons yang positif dari guru. Bentuk komunikasi dijalankan secara dialog dan multi arah, dalam arti mengacu kepada potensi yang dimiliki oleh komite sekolah atau guru dan staf kepala sekolah rnampu menempatkan diri dalam kelompok kerja. Proses pengawasan berlangsung melalui evaluasi tugas mengajar, persiapan pemeriksaan mengajar dan evaluasi secara keseluruhan yang berkaitan dengan kinerja guru. Dalam berkomunikasi dengan bawahan, kepala sekolah selalu bersikap terbuka terhadap semua hal sehingga tidak ada rasa kecanggungan terhadap guru,akan tetapi tidak mengabaikan kode etik dalam organisasi dan jenjang. kepangkatan.

Dalam keterampilan konseptual (conceptual skill), selain menggerakkan komponenkomponen sekolah, kepala sekolah selalu merencanakan sebuah perubahan untuk kemajuan sekolah. Hal ini dapat dilihat dari upaya kepala sekolah selalu melaksanakan pernbangunan insfrastruktur setiap tahunnya secara bertahap. Koordinasi juga dilakukan secara harmonis dengan pihak-pihak terkait. .Dalam organisasi pendidikan keterampilan konsep adalah keterampilan yang dimiliki oleh kepala sekolah sebagai suatu keseluruhan, merencanakan perubahan, merancang tujuan sekolah, membuat penilaian secara tepat tentang efektifitas kegiatan sekolah dan mengkoordinasikan program secara harmonis.

Dari uraian di atas dapat dijelaskan bahwa kepala sekolah memiliki kematangan baik dari sisi pekerjaan ataupun psikologis. Dalam hal ini kepala sekolah dengan kematangan pekerjaannya memiliki pengetahuan dan pengalaman untuk melaksanakan tugastugasnya dan dengan kematangan psikologis dapat memotivasi orang lain untuk melakukan pekerjaan.

Dalam proses peningkatan kinerja guru, kepala sekolah sebagai figur kunci dalam mendorong perkembangan dan kemajuan sekolah. Kepala sekolah sebagai pendidik selain mengatur sekolah secara umum juga melakukan tata ruang yang memberikan kenyamanan baik bagi dewan guru maupun bagi siswa serta memberikan pembelajaran baik pada guru dan staf. Oleh karena itu maka kepala sekolah juga menjadi guru dalam bidang bimbingan dan penyuluhan. Membimbing guru dalam menyusun, melaksanakan program pembelajaran sampai teknik evaluasi bagian dari pekerjaan yang dilaksanakan oleh kepala sekolah. Dalam rangka meningkatkan kinerja guru, guru didorong, untuk mengikuti pelatihanpelatihan yang memberikan pengalaman dan pengetahuan.hal ini di maksud untuk memberi pengetahuan baru dan juga pengalaman untuk mengembangkan kemampuan intra dan antar sekolah.

Dalam membuat perencanaan pembelajaran rata-rata guru SMK Yasmida Ambarawa belum membuat perangkat pembelajaran dengan baik .sehingga mereka mengumpulkannya juga masih terlambat. Hal ini disebabkan oleh kurangnya kemampuan guru dalam menyusun RPP, karena mesti ada guru yang belum berpendidikan S.I.

Penguasaan bahan pelajaran ternyata memberikan pengaruh terhadap hasil belajar siswa. Selanjutnya penulis akan mengemukakan tentang kemampuan guru dalam melaksanakan atau mengelola proses belajar mengajar. Adapun yang menjadi indikatornya adalah: mampu membangkitkan motivasi siswa, mmemberikan apersepsi kepada siswa, mampu menggunakan metode mengajar yang bervariasi, mampu menggunakan alat bantu pengajaran, mampu mengatur dan mengubah suasana kelas, mampu memberikan teguran siswa, mampu mengatur siswa, mampu memberikan reward dan sangsi pada siswa dan mampu memberikan pujian kepada siswa. Dalam hal menguasai bahan pengajaran, dapat penulis jelaskan bahwa guru-guru telah mampu menjelaskan materi pelajaran dengan baik dan mampu menjawab soal/pertanyaan dari siswa. Dalam melakukan evaluasi rata-rata kemampuan guru telah memiliki kemampuan yang baik dalam membuat dan mengoreksi soal. Rata-rata Guru telah melaksanakan remidial dan pengayaan, sehingga keobjektifan penilaian dalam raport dapat berkurang Keterangan lain menjelaskan dalam UU No. 14 Tahun 2005 Bab IV Pasal 20 (a) tentang Guru dan Dosen menyatakan bahwa standar prestasi kerja guru dalam melaksanakan tugas keprofesionalannya, guru berkewajiban merencanakan pembelajaran, melaksanakan proses pembelajaran yang bermutu serta menilai dan mengevaluasi hasil pembelajaran.

Dalam konteks ini, program peningkatan mutu kinerja guru sangat relevan dan sangat strategis, untuk mengembangkan kreativitas siswa sekaligus peningkatan hasil belajar siswa mengingat fungsi dan perannya sebagai pengelola disatuan lembaga pendidikan di tingkat operasional. Guru merupakan profesi 
profesional dimana ia dituntut untuk berupaya semaksimal mungkin menjalankan profesinya sebaik mungkin sebagai seorang profesional maka tugas sebagai pendidik, pengajar dan pelatih hendaknya dapat berimbas kepada siswanya. Dalam hal ini guru hendaknya dapat meningkatkan terus kinerjanya yang merupakan modal bagi keberhasilan pendidikan. kinerja adalah kuantitas dan kualitas pekerjaan yang diselesaikan oleh individu, maka kinerja merupakan output pelaksanaan tugas. Kinerja untuk tenaga guru ummnnya dapat diukur melalui: (1) kemampuan membuat rencana pelajaran. (2) kemampuan melaksanakan rencana pelajaran; (3) kemampuan melaksanakan evaluasi.

\section{DAFTAR PUSTAKA}

Al Quran dan terjemahanya. 1989. Diterjemahkan oleh Tim Penerjemah Karya Toha Putra. Semarang : Karya Toha Putra.

Arifin A. 2003. Memahami Paradigma Baru Pendidikan Nasional dalam UndangUndang Sisdiknas, (Jakarta: Depag RI), cet, ke-2

Departemen Agama Republik Indonesia, AIqur'an Dan Terjemah (Semarang : CV Thoha Putra 1989 )

Dewi, IKAS., dkk. 2014. Kontribusi Sikap Profesional Guru, Gaya Kepemimpinan Kepala Sekolah, Dan Motivasi Kerja Terhadap Kinerja Guru Di Smp Negeri 4 Abiansemal. E-journal Program Pascasarjana Universitas Pendidikan Ganesha. Program Studi Administrasi Pendidikan. Hal. 1., Volume 5.

Hadari Nawawi. 1996. Administrasi Pendidikan, (Jakarta: PT. Gunung Agung), h. 34

Hidayati. 2014. Manajemen Pendidikan, Standar Pendidik, Tenaga Kependidikan, dan Mutu Pendidikan. Jurnal Al-Ta 'tim. Volume 21, Nomor I Februari 2014, Hlm. 42-53. Jurusan Pendidikan Guru Madrasah Ibtidayah. Fakultas Tarbiyah dan Keguruan IAIN IB Padang

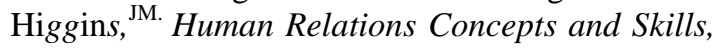
(New York : Random House, 1985, Hal 34

James AF. Stoner, (Jakarta: Prenhallindo, 1996)

Siagaan S. 2002. Fungsi-Fungsi Manajerial, (Jakarta: Bumi Aksara)

Sudarman Danim . 2011. Motivasi Kepemimpinan dan Efektifitas dan Kelompok, ( Jakarta : Prenada Media ) h 111

Sukmadinata, N. 2005. Metode Penelitian Pendidikan (Bandung : Remaja Rosdakarya) 